\title{
Occurrence of Cryptococcus neoformans in the excreta of urban pigeons in the municipality of Redenção in Amazônia, Brazil
}

\author{
Ocorrência de Cryptococcus neoformans nas excretas de pombos urbanos no município de Redenção na \\ Amazônia, Brasil
}

\section{Edlainny Araujo Ribeiro ${ }^{1 *}$, Georgia Miranda Tomich ${ }^{2}$, Joicy Araújo Gomes Alves ${ }^{3}$, Karoline Santos e Santos ${ }^{3}$}

\begin{abstract}
Resumo
Atualmente, os ecossistemas urbanos tornaram-se cada vez mais propícios aos pombos, e a população dessas aves aumentou significativamente em várias partes do mundo, incluindo o Brasil. Esse aumento se tornou um problema ambiental e de saúde pública. O objetivo desta pesquisa foi descrever a ocorrência de Cryptococcus neoformans nos excrementos de pombos em locais públicos do município de Redenção, Pará, Brasil. Trata-se de um estudo transversal, quantitativo e descritivo. Foram selecionados dez bairros, onde foram coletadas 5 amostras de cada um, totalizando 50 unidades de material. O fungo foi identificado através de excrementos suspensos com solução estéril de cloreto de sódio a $0,9 \%$, seguida de semeadura em ágar Sabouraud Dextrose mais cloranfenicol. Um exame direto das colônias com tinta chinesa foi realizado em triplicata para observar a sugestiva micromorfologia de $C$. neoformans. Um teste de identificação confirmatória foi realizado pelo teste de produção de urease. Das 50 amostras examinadas, $16 \%(\mathrm{n}=8)$ foram positivas para $C$. neoformans e nos 10 bairros estudados, $60 \%(\mathrm{n}=6)$ foram positivos para o fungo. Os resultados mostraram que metade das amostras positivas foram encontradas em apenas dois bairros, sugerindo que a presença de C. neoformans em local público na cidade estudada pode ser considerada uma fonte potencial de infecção para humanos e animais.

Palavras-chave: Pombos, excreta; Cryptococcus neoformans; microbiologia ambiental.
\end{abstract}

\begin{abstract}
Currently, urban ecosystems have become increasingly conducive to pigeons, and the population of these birds has increased significantly in several parts of the world, including Brazil. This increase has become an environmental and public health problem. The objective of this research was to describe the occurrence of Cryptococcus neoformans in the excreta of pigeons in public places in the municipality of Redenção, Pará, Brazil. It is a cross-sectional, quantitative, and descriptive study. Ten neighborhoods were selected, where 5 samples from each were collected, for a total of 50 units of material. Fungus was identified through suspended excreta with a sterile $0.9 \%$ sodium chloride solution, followed by seeding on Sabouraud Dextrose agar plus chloramphenicol. A direct examination of the colonies with Chinese ink was done in triplicate to observe the suggestive micromorphology of $C$. neoformans. A confirmatory identification test was performed by the urease production test. Of the 50 samples examined, $16 \%(\mathrm{n}=8)$ were positive for $C$. neoformans, and in the 10 neighborhoods studied, $60 \%(\mathrm{n}=6)$ were positive for the fungus. The results showed that half of the positive samples were found in only two neighborhoods, suggesting that the presence of $C$. neoformans in a public place in the studied city can be considered a potential source of infection for humans and animals.
\end{abstract}

Keywords: Pigeons, excreta, Cryptococcus neoformans, environmental microbiology.

\section{Introduction}

Currently, the urban ecosystem has become increasingly favorable for pigeon permanence. The increase of their colonies is mainly due to the quantity of food available in public environments, leading to the accumulation of excreta, which is considered an important source of infection for humans and animals. In addition, the population of these poultry has increased significantly in diverse parts of the world, including in Brazil; the increased population has become an environmental and public health problem (MARENZONI et al., 2016).

\footnotetext{
㐫 Edlainny Araujo Ribeiro dyy_araujo77@hotmail.com
}

${ }^{1}$ Docente Microbiologia Médica na Faculdade de Ensino Superior da Amazônia Reunida.

${ }^{2}$ Coordenadora de Pesquisa e Extensão Faculdade de Ensino Superior da Amazônia Reunida.

${ }^{3}$ Discente Faculdade de Ensino Superior da Amazônia Reunida
The dry excreta offers an organic substrate more favorable for the development of the fungus Cryptococcus neoformans because there is a smaller amount of bactéria present reducing the competition for growth; the reduced competition favors the formation of microfocus in urban centers, leading to daily human exposure to this pathogen, for example, in domestic dust (REOLON et al., 2004).

The fungus is an encapsulated basidiomycete in spherical or globose form with a diameter of approximate $2-8 \mu \mathrm{m}$. Reproduction of the fungus is through budding, and the fungus has a capacity growth at $37^{\circ} \mathrm{C}$ (ZARAGOZA et al., 2010). It has an antigenic mucopolysaccharide capsule, which is responsible for protection against phagocytic cells (TORTORA et al., 2017).

The yeast presents great clinical relevance as the remains are viable in the dry feces of pigeons for approximately two years because it resists desiccation. The fungus survives well 
when it is not exposed directly to sunlight and when it is protected from high temperatures (MEZZARI et al., 2014). The high corporeal temperature of pigeons $\left(42^{\circ} \mathrm{C}\right)$, associated with augmented macrophage activity, restricts cryptococcal growth in these birds (JOHNSTON et al., 2016).

In humans, the pathogen causes cryptococcosis, which is transmitted after inhalation of infectious propagules containing $C$. neoformans from avian excrement, especially that of pigeons (Columba livia) (ESHER et al., 2018). If dissemination occurs via hematogenous, the fungus can reach other organs and even the central nervous system. This opportunistic infection mainly affects immunocompromised patients (MAZIARZ e PERFECT, 2016).

In Brazil, the disease presents itself as the second cause of death among systemic mycoses, and it has a lethality rate in the range of (45\%) to (65\%) (DEVI et al., 2013; GOUVEIA et al., 2018). It is appropriate to highlight the environmental dissemination of $C$. neoformans, and this finding may contribute to the elevation of these indices (LEITE et al., 2012). However, cryptococcosis is not considered a compulsory notification, so data on this mycosis are known from case series analyses and are diagnosed in some regional centers (BANERJEE, 2005; MOREIRA et al., 2017). Most cases of cryptococcosis are concentrated in the southeastern and southern regions; there is a lack of data from other regions of Brazil (TRILLES et al., 2012; ALBUQUERQUE e RODRIGUES, 2012).

Therefore, cryptococcosis can be considered both an environmental and public health problem, since it mainly affects immunosuppressed patients, presenting high morbidity and mortality indices. Thus, considering the scarcity of studies in the northern region of Brazil, and the possibility of the environment being a source of dissemination of the etiological agent, it becomes relevant to carry out this study. This study will contribute to the elaboration of health policies and perfecting the control and prevention measures of sanitary risk.

The objective of this research was to describe the occurrence of Cryptococcus neoformans in the excreta of pigeons in public places in the municipality of Redenção, Pará, Brazil.

\section{Material and methods}

\section{Studied area}

This is a descriptive, prospective, cross-sectional and quantitative study conducted in public places of Redenção, Pará, Brazil ( $8^{\circ} 2^{\prime} 35^{\prime}$ " south, longitude $50^{\circ} 1^{\prime} 22^{\prime \prime}$ west). This area has approximately 83,977 inhabitants, corresponding to a density of $19.76 \mathrm{hab} . / \mathrm{km}^{2}$. It is at an elevation of $227 \mathrm{~m}$ above sea level and has a tropical climate with maximum temperatures of approximately $43.01{ }^{\circ} \mathrm{C}$ and minimum temperatures of $24.71^{\circ} \mathrm{C}$. Only $10 \%$ of the households have adequate sanitary sewage, and $59.6 \%$ of the urban households on public roads have vegetation (IBGE, 2017).

\section{Criteria for selection of samples}

The city has 33 neighborhoods, including a downtown and the peripheral sectors. The neighborhoods were selected for the study following the observational criteria of people flow and a large concentration of pigeons. In this way, 10 neighborhoods were selected, 5 samples each were randomly collected from different sites, totaling 50 units of material (Figure 1) (ROSA et al., 2016).

The study was carried out with excreta of urban pigeons, considering sites that presented, concomitantly, deposited or accumulation of their waste in the soil. We included dried out excreta, deposited on the surfaces of public environments, with the presence of pigeons near the excreta and sufficient quantities for further microbiological analysis. We excluded samples with small quantities that would make analysis impossible (TAKAHARA et al., 2013).

\section{Isolation and phenotypic identification}

The technical procedure for the isolation of $C$. neoformans was adopted following validated methodologies, using the standard strain $\left(\mathrm{ATCC}^{\circledR} 90112^{\mathrm{TM}}\right.$ ). For this, the avian excrements were packed in sterile bottles and transported to the laboratory of microbiology of the Faculdade de Ensino Superior da Amazônia Reunida (FESAR), located in the same municipality as the collections. The flasks were kept at room temperature, and in less than 24 hours, all the bird droppings were crunch (CONTIN et al., 2011; RIBEIRO et al., 2017).

The suspension was performed using $0.5 \mathrm{~g}$ of the material in $5 \mathrm{~mL}$ of a sterile $0.9 \%$ sodium chloride solution, vortexed for 3 minutes, and allowed to settle for 30 minutes at room temperature. After that time, $100 \mu \mathrm{l}$ of the supernatant was seeded on Sabouraud Dextrose agar plus chloramphenicol $\left(\right.$ Probac $\left.^{\circledR}\right)$, with the aim of inhibiting bacterial growth. The plates were incubated in an oven at $30^{\circ} \mathrm{C}$ for 5 days (CONTIN et al., 2011).

For the direct examination, $100 \mu \mathrm{l}$ of the suspension obtained from the culture plus $50 \mu \mathrm{l}$ of Chinese ink $\left(\right.$ Renylab $\left.^{\circledR}\right)$ was used for microscopic analysis. The characteristic colonies were analyzed by two methods: the first consisted of direct examination with Chinese ink; the second proceeded with the preparation of a suspension with $50 \mu \mathrm{l}$ of a physiological solution and $50 \mu \mathrm{l}$ of Chinese ink to visualize the micromorphology of the fungus. Therefore, the 50 samples were visualized in triplicate for validation (RIBEIRO et al., 2017).

A confirmatory identification test was performed using the urease production test $\left(\operatorname{Laborclin}^{\circledR}\right)$. For this test, a 


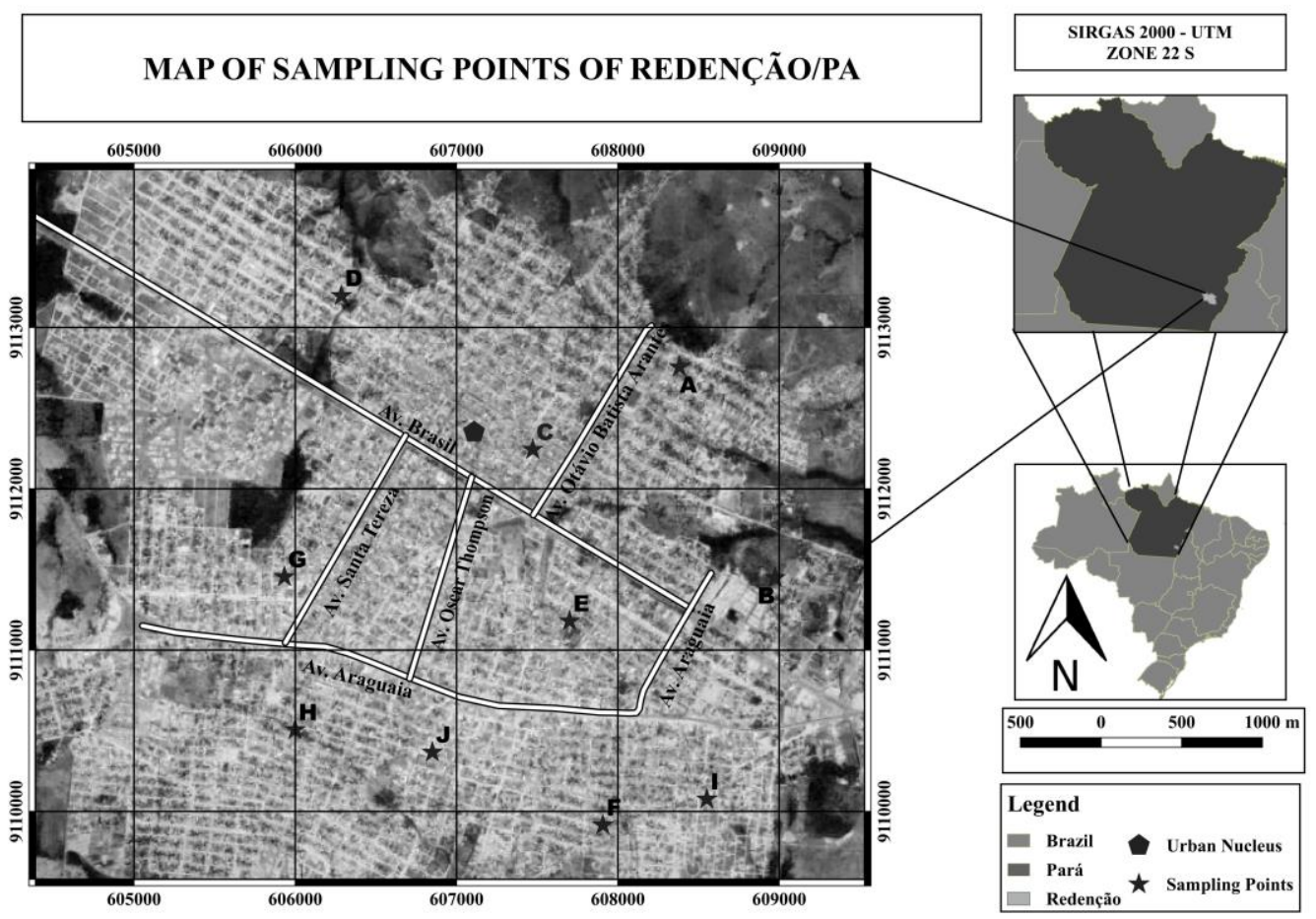

Figure 1. Demonstration of the neighborhoods selected for the collection of samples, in the city of Redenção, Pará, Brazil, 2018.

colony was transferred to a tube containing the urea medium. This tube was proceeded by homogenization and subsequent incubation in an oven at $30^{\circ} \mathrm{C}$ for a period of seven days. A positive result was evidenced from the alteration of the color of the medium to a pink or red color (CONTIN et al., 2011).

\section{Statistical analysis}

For tabulation of the data, the places were grouped as follows: group I (five squares), group II (eleven health units), group III (ten educational institutions) and group IV (twenty-four open areas nearby residences, streets and public areas). The results were analyzed using descriptive statistics. The data were organized and explained in the form of tables and graphs, having the support of the program Microsoft Office Excel, version 14.0.

\section{Ethical Considerations}

Following the guidelines of Resolution 466/12 of the National Health Council, the research project was not submitted to the Ethics Committee. Just as it was dispensed from the National Council for Control of Animal Experimentation - CONCEA, this was because the focus of the study was only on the bird droppings dispersed in the soil. However, we attend the determinations contained in Resolution 441/12 of the National Health Council.

\section{Results}

Of the 50 samples examined, $16 \%(\mathrm{n}=8)$ were positive for $C$. neoformans. Of the 10 neighborhoods studied, $60 \%(\mathrm{n}=6)$ were positive for the fungus, noting that the $\mathrm{D}$ and $\mathrm{E}$ neighborhoods had the highest number of positive cultures $50 \%$ $(n=4)$. The occurrence of yeast was equal in neighborhoods A, F, H and J. In contrast, in neighborhoods B, C, G and I, all samples analyzed were negative (Figure 2).

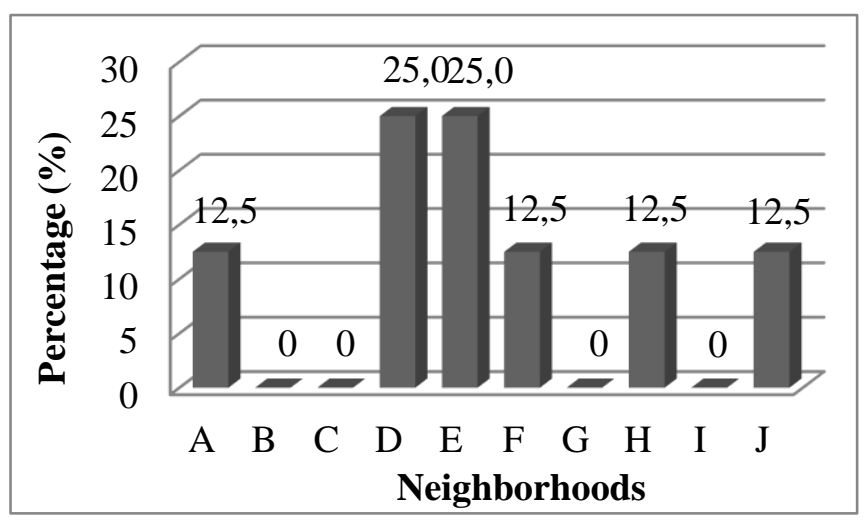

Figure 2. Demonstration of the neighborhood distribution of the positive samples of Cryptococcus neoformans in excreta of pigeons in the city of Redenção, Pará, Brazil, 2018.

With relation to the total number of positive cultures $(n=8)$ analyzed by groups, the presence of the fungus was detected more frequently in open areas $(n=4 ; 50 \%)$. While in

Table 1. Types, number of sites investigated (groups) and positive samples (\%) of Cryptococcus neoformans in excreta of pigeons in the city of 
Redenção, Pará, Brazil, 2018.

\begin{tabular}{|c|c|c|c|c|c|}
\hline \multirow{3}{*}{ Groups/Location } & \multirow{3}{*}{$\begin{array}{l}\text { Locations with } \\
\text { presence of } \\
\text { excreta }(n)\end{array}$} & \multicolumn{4}{|c|}{ Isolation } \\
\hline & & \multicolumn{2}{|c|}{ Positive } & \multicolumn{2}{|c|}{ Negative } \\
\hline & & Absolute (n) & Relative (\%) & Absolute (n) & Relative (\%) \\
\hline I: squares & 5 & - & - & 5 & 100 \\
\hline II: health units & 11 & 2 & 18,1 & 9 & 81,9 \\
\hline III: educational institutions & 10 & 2 & 20,0 & 8 & 80,0 \\
\hline IV: open areas & 24 & 4 & 16,6 & 20 & 83,4 \\
\hline TOTAL & 50 & 8 & 16 & 42 & 84 \\
\hline
\end{tabular}

Conventional used signal: Numeric data equal to zero, not resulting from rounding.

health units and educational institutions, a lower number of positive samples were verified $(n=2 ; 25 \%)$ and $(n=2 ; 25 \%)$, respectively. On the other hand, in one group (squares), the samples resulted in negative cultivations (Table 1). The presence of yeast structures with formation of pseudohyphae suggestive of Candida sp. was observed in most samples that were analyzed.

\section{Discussion}

Fungi are commonly underestimated as etiological agents of human diseases, and deaths resulting from fungal infections are often neglected. Since the epidemiology of these pathogenic agents is dynamic and difficult to predict, more research on their occurrence is essential (GIACOMAZZI et al., 2016; KÖHLER et al., 2017).

This study showed positive evidence for the isolation of $C$. neoformans, concordant with the results of other research that reported percentages of $(13 \%),(16 \%),(22 \%)$ and $(100 \%)$. It is worth mentioning that in this last research, the city had an average temperature of $24.5^{\circ} \mathrm{C}$, a determinant factor in the variation of results (PEDROSO et al., 2009; CORRÊA et al., 2011; ARAÚJO JÚNIOR et al., 2015; NWEZE et al., 2015).

On the day of sample collection for the study, the county surveyed presented low humidity, a temperature of approximately $38^{\circ} \mathrm{C}$ and a scarcity of rainfall for a few months. The high temperature associated with low humidity are factors that contribute to the inactivation of the microorganism, consequently the viability of the yeasts in the environment is reduced. It can be assumed that different climatic characteristics could result in higher rates of prevalence (ISHAQ et al., 1967; ROBERT et al., 2015).

In a study that evaluated the best survival conditions of $C$. neoformans, the researchers demonstrated that the geographic region with the highest probability of presence was in the center of Portugal, where summers are particularly rainy due to the humid currents of the Atlantic Ocean (MENEZES et al., 2014; COGLIATI et al., 2017).

According to the pathogenic fungi species, thermotolerance is more commonly found in the studied species. There is also evidence that they grow faster at warmer temperatures in urban areas than their rural homologues (GARCIA-SOLACHE e CASADEVALL, 2010).

According to the different groups studied, only squares resulted in negative crops. However, a positive isolation of $(7.1 \%)$ was observed in the squares of Pelotas, Rio Grande do Sul, and these had adequate vegetation to protect the material from solar radiation (avoiding denaturation); this was an environmental characteristic not seen in the other squares that were sampled. The open areas had a predominance of positive samples. This result is explained by the fact that most of these locations present partial coverage with asbestos, protecting avian excrements from direct sunlight (FARIA et al., 2010).

Positive samples were observed in samples from health units and educational institutions. The presence of this agent in these areas is worrisome, since it corresponds to environments that have risk groups for the development of cryptococcosis. Other research exhibited positive results of $(32.5 \%)$ and $(56.1 \%)$ of yeast isolates in these areas, highlighting a concern in the control of birds (ANDRADE et al., 2010; LIMA et al., 2015).

There were difficulties in the laboratory detection of $C$. neoformans; this fact is due to the rapid and abundant growth of environmental fungi, mainly zygomycetes, having impaired growth and visualization of the fungal colonies (KOBAYASHI et al., 2005).

Considering the micromorphology, the presence of round blastoconiids with capsules around them were observed; however, there was a weak reaction when examined with Chinese ink. Its usefulness as a diagnostic technique presents a disadvantage to the research on capsules; this disadvantage is due to the addition of thimerosal to the preparation of the ink making it toxic to C. neoformans (PAES et al., 2018). Other interferents may be cited as variations of $\mathrm{pH}$, osmolarity, carbon source and nutrient concentration (MUKAREMERA et al., 2018).

Moreover, fungal resistance to antimicrobials is not well studied compared to gram-negative pathogens or tuberculosis. Therefore, the available options are limited and may be problematic due to drug interactions and toxicity. Resistance to antifungal drugs is still not as an urgent a priority as resistance to bacterial infections, but we should be proactive in dealing with probable future loads of resistance (HEAD et al., 2014).

Although scarce, there are already studies in Brazil whose determination of susceptibility profiles revealed the presence 
of $C$. neoformans isolates resistant to the antifungal agents tested. This monitoring is recommended to detect the rise of any resistant strains, resulting in better stewardship of patients with cryptococcosis (MATOS et al., 2012; GUTCH et al., 2015). Therefore, the emergence of unprecedented yeast is an opportune reminder of the same situation with bacteria, and fungal pathogens deserve equal attention regarding infection control, antifungal management and the breakdown of epidemiological dissemination and the environment (CHOWDHARY et al., 2017; LAMOTH e KONTOYIANNIS, 2018).

Thus, with the advent of this resistance, the infections caused by this pathogen should receive greater attention. The acquisition of $C$. neoformans infections in people with HIV/AIDS is up to 220,000 cases occurring annually in the world (CDC, 2018; RAJASINGHAM et al., 2017). A survey conducted in China with 954 cases of HIV infection found that (7.3\%) had association with cryptococcal infection (PANG et al., 2018). In Brazil, a study showed that most isolates of $C$. neoformans $(87.5 \%)$ were obtained from patients with HIV (NUNES et al., 2018).

Other research have analyzed the mortality associated with C. neoformans infection in patients with lymphoproliferative neoplastic disturbances and nephrotic syndromes, evidencing indices of (46\%) and (35\%), respectively (FANG et al., 2017; DIOVERTI et al., 2018).

However, the ability of yeast to bring harm is not restricted to individuals with compromised immune systems. Research developed in Brazil with immunocompetent patients affected by cryptococcosis showed impairments associated with the central nervous system in $(86.2 \%)$ of them. The associated mortality was described as (20.7\%) (LOMES et al., 2016). In China, this disease has affected children without underlying conditions and has shown similar consequences (LIU et al., 2017).

However, cryptococcosis has indices of support disproportionate to its importance, receiving less than $0.5 \%$ of global funding. In scientific activities, cryptococcal meningitis received approximately 100 times less funding compared to malaria and tuberculosis and 25 times less funding compared to diarrheal diseases. Although cryptococcal meningitis kills 20 times more individuals than Neisseria meningitidis, funding research on bacterial meningitis have been 4.35 times higher than that available for fungal disease (ALBUQUERQUE e RODRIGUES, 2018).

It is known that birds are a reservoir that contributes to the global dispersion of this pathogen in the environment. Although the fungus is associated with pigeon feces, its primary habitat can be considered species of plants and aged wood. Nevertheless, it can interact and infect many soil microbes using many of its virulence attributes, promoting its dissemination (KOZUBOWSKI et al., 2012).

Through exposure, it becomes pertinent to apply measures of prevention and control of these populations in public places in order to reduce the avian excrement deposited in these environments. Thus, it is necessary that the education of the public and health professionals be complementary to the efforts for infection control and antifungal manipulation (MIRANDA et al., 2014).

\section{Conclusion}

From the results obtained, it was verified that only two of the ten districts sampled have half of the positive samples, suggesting that the presence of $C$. neoformans in the environment can be considered an important source of infection for humans and animals.

However, this being the first study on the yeast in the region, it opens an interesting perspective to better establish such characteristics. This study contributes to the elaboration of public health policies in order to improve the control and prevention measures of sanitary risk directed to this zoonosis. In addition, further studies can be based on clarifying the correlation between environmental dissemination and cryptococcosis indices in this region.

\section{Acknowledgements}

The authors are grateful to the employees of the Laboratory of Microbiology of the Faculdade de Ensino Superior da Amazônia Reunida.

\section{Financial Support}

The research was funded by the authors themselves. The Faculdade de Ensino Superior da Amazônia Reunida supported by providing equipment, materials and providing the facilities of the Microbiology laboratory to carry out the analyzes.

\section{Conflict of Interest}

The authors declare no conflicts of interest.

\section{References}

ALBUQUERQUE, P.C.; RODRIGUES, M.L. Research trends on pathogenic Cryptococcus species in the last 20 years: A global analysis with focus on Brazil. Future Microbiology, v. 7, p. 319-329, 2012.

ALBUQUERQUE, P.C.; RODRIGUES, M.L. Searching for a change: The need for increased support for public health and research on fungal diseases. PLoS Neglected Tropical Diseases, v. 12, p. 1-5, 2018.

ANDRADE, S.L.; FERREIRA, P.K.; SILVA, V.M.L; PEDROSA, A.L. Molecular characterization and evaluation of virulence factors of Cryptococcus laurentii and Cryptococcus neoformans strains isolated from external hospital areas. Fungal Biology, v. 114, 
p. $438-445,2010$.

ARAÚJO JÚNIOR, E.C.; TÁPARO, C.V.; UCHIDA, C.Y.; MARINHO, M. Cryptococcus: isolamento ambiental e caracterização bioquímica. Arquivos Brasileiros de Medicina Veterinária e Zootecnia, v. 67, p. 1003-1008, 2015.

BANERJEE U. Progress in the diagnosis of opportunistic infections in HIV/AIDS. Indian Journal of Medical Research, v. 121, p. 395-406, 2005.

BRASIL. Ministério da Saúde. Conselho Nacional de Saúde.

Resolução 466; 2012 Disponível em: http://bvsms.saude.gov.br/bvs/saudelegis/cns/2013/res0466 _12_12_2012.html. Acesso em 9 de novembro de 2018.

BRASIL. Ministério da Saúde. Conselho Nacional de Saúde.

Resolução 441; 2011 Disponível em: http://conselho.saude.gov.br/resolucoes/2011/reso441.pdfA cesso em 9 de novembro de 2018.

CHOWDHARY, A.; SHARMA, C.; MEIS, J.F. Candida auris: A rapidly emerging cause of hospital-acquired multidrug-resistant fungal infections globally. PLoS Pathogens, v. 13, p. 1-10, 2017.

COGLIATI, M.; PUCCIANTI, E.; MONTAGNA, M.T.; DONNO, A.; SUSEVER, S.; ERGIN, C.; et al. Fundamental niche prediction of the pathogenic yeasts Cryptococcus neoformans and Cryptococcus gattii in Europe. Environmental Microbiology, v. 19, p. 4318-4325, 2017.

CDC. Centers for Disease Control and Prevention. $C$. neoformans Infection Statistics. Disponível em: https://www.cdc.gov/fyngal/diseases/cryptococcosis-neofor mans/statistics.html. Acesso em 5 de novembro de 2018.

CONTIN, J.T.; QUARESMA, G.S.; SILVA, E.F.; LINARDI, V.R. Ocorrência de Cryptococcus em fezes de pombos na cidade de Caratinga, MG - Brasil. Revista Médica de Minas Gerais, v. 21, p. 19-24, 2011.

CORRÊA, E.A.; NACONECHNY, F.; CASAGRANDE, L.P. Presença de Cryptococcus neoformans em excretas de Columba sp. na cidade de Cacoal, Rondônia, Brasil. Revista Igapó - IFAM, v. 5, p. 54-60, 2011.

DEVI, S.B.; NINGSHEN, R.; ARVIND, G.; SYNREM, E.; DEVI, T.S.; SINGH, T.B. Prevalence of cryptococcal meningitis in patients of acquired immunodeficiency syndrome: a single center experience from Regional Institute of Medical Sciences. Journal of Medical Society, v. 27, p. 56-60, 2013.

DIOVERTI, M.V.; PARIKH, S.A.; OSMON, D.R.; HABERMANN, T.M.; TANDE, A.J. Cryptococcus neoformans infections in patients with lymphoproliferative neoplasms. Leukemia \& Lymphoma, v. 6, p. 1-7, 2018.

ESHER, K.S.; ZARAGOZA, O.; ALSPAUGH, J.A. Cryptococcal pathogenic mechanisms: a dangerous trip from the environment to the brain. Memórias do Instituto Oswaldo Cruz, v. 113, p. 1-15, 2018.

FANG, W.; HONG, N.; LI, Y.; LIU, J.; ZHANG, L.; JIANG, W. et al. Cryptococcosis in patients with nephrotic syndrome: a pooled analysis of cases. Mycopathologia, v.
182 , p. $517-525,2017$.

FARIA, R.O.; NASCENTE, P.S.; MEINERZ, A.R.M.; CLEFF, M.B.; ANTUNES, T.A.; SILVEIRA, E.S., et al. Ocorrência de Cryptococcus neoformans em excretas de pombos na Cidade de Pelotas, Estado do Rio Grande do Sul. Revista da Sociedade Brasileira de Medicina Tropical, v. 43, p. 198-200, 2010.

GARCIA-SOLACHE, M.A.; CASADEVALL, A. Global warming will bring new fungal diseases for mammals. MBio, v. 1, p. 1-3, 2010.

GIACOMAZZI, J.; BAETHGEN, L.; CARNEIRO, L.C.; MILlingTON, M.A.; DENNING, D.W.; COLOMBO, A.L., et al. The burden of serious human fungal infections in Brazil. Mycoses, v. 59, p. 145-150, 2016.

GOUVEIA, V.A.; FERNANDES, B.F.S.; FROTA, E.R.C.; CUNNINGHAN, M.C.Q.S.; CHRISTO, P.P.; GOMEZ, R.S., et al. Clinical laboratory characteristics of cryptococcosis in patients admitted to the emergency room hospital das clínicas, Federal University of Minas Gerais, tertiary reference of the unified health system: retrospective analysis from 2000 to 2013. Revista Médica de Minas Gerais, v. 28, p. 1-12, 2018.

GUTCH, R.S.; NAWANGE, S.R.; SINGH, S.M.; YADU, R.; TIWARI, A.; GUMASTA, R., et al. Antifungal susceptibility of clinical and environmental Cryptococcus neoformans and Cryptococcus gattii isolates in Jabalpur, a city of Madhya Pradesh in Central India. Brazilian Journal of Microbiology, v. 46, p. 1125-1133, 2015.

HEAD, M.G.; FITCHETT, J.R.; ATUN, R.; MAY, R.C. Systematic analysis of funding awarded for mycology research to institutions in the UK, 1997-2010. BMJ Open, v. 4, p. 1-6, 2014.

IBGE. Instituto Brasileiro de Geografia e Estatística. Cidades. Brasil: IBGE; 2018. Disponível em: https://cidades.ibge.gov.br/brasil/pa/ redencao/panorama. Acesso em 20 de agosto de 2018.

ISHAQ, C.M.; BULMER, G.S.; FELTON, F.G. An evaluation of various environmental factors affecting the propagation of Cryptococcus neoformans. Mycopathologia et Mycologia Applicata, v. 35, n. 2, p. 81-90, 1968.

JOHNSTON, S.A.; VOELZ, K.; MAY, R.C. Cryptococcus neoformans thermotolerance to avian body temperature is sufficient for extracellular growth but not intracellular survival in macrophages. Scientific Reports, v. 6, p. 1-9, 2016.

KOBAYASHI, C.C.B.A.; SOUZA, L.K.H.; FERNANDES, O.F.L.; BRITO, S.C.A.; SILVA, A.C.; SOUSA, E.D., et al. Characterization of Cryptococcus neoformans isolated from urban environmental sources in Goiânia, Goiás State, Brazil. Revista do Instituto de Medicina Tropical de São Paulo, v. 47, p. 203-207, 2005.

KÖHLER, J.R.; HUBE, B.; PUCCIA, R.; CASADEVALL, A.; PERFEITO, J. Fungi that infect humans. Microbiology 
Spectrum, v. 5, p. 813-843, 2017.

KOZUBOWSKI, L.; HEITMAN, J. Profiling a killer, the development of Cryptococcus neoformans. FEMS Microbiology Reviews, v. 36, p. 78-94, 2012.

LAMOTH, F.; KONTOYIANNIS, D.P. The Candida auris Alert: Facts and Perspectives. The Journal of Infectious Diseases, v. 217, p. 516-520, 2018.

LEITE, D.P.; AMADIO, J.V.R.S.; MARTINS, E.R.; SIMÕES, S.A.A.; YAMAMOTO, A.C.A.; LEAL, F.S., et al. Cryptococcus spp. isolated from dust microhabitat in Brazilian libraries. Journal of Occupational Medicine and Toxicology, v. 7, p. 1-7, 2012.

LIMA, C.T.; KLAFKE, G.B.; XAVIER, M.O. Cryptococcus spp. em excretas de Columba livia (pombos domésticos) provenientes de um hospital universitário no Sul do Brasil. Arquivos do Instituto Biológico, v. 82, p. 1-4, 2015.

LIU, L.; GUO, L.; LIU, Y.; CHEN, T., LI, S.; YANG, Y. et al. Clinical characteristics and prognosis of pediatric cryptococcosis in Beijing Children's Hospital, 2002-2014. European Journal of Pediatrics, v. 176, p. 1235-1244, 2017.

LOMES, N.R.; MELHEM, M.S.C.; SZESZS, M.W.; MARTINS, M.A.; BUCCHERI, R. Cryptococcosis in nonHIV/non-transplant patients: A Brazilian case series. Medical Mycology, v. 54, p. 669-676, 2016.

MARENZONI, M.L.; MORGANTI, G.; MORETTA, I.; CROTTI, S.; AGNETTI, F.; MORETTI, A. et al. Microbiological and parasitological survey of zoonotic agents in apparently healthy feral pigeons. Polish Journal of Veterinary Sciences, v. 19, p. 309-315, 2016. MATOS, C.S.; ANDRADE, A.S.; OLIVEIRA, N.S.; BARROS, T.F. Microbiological characteristics of clinical isolates of Cryptococcus spp. in Bahia, Brazil: molecular types and antifungal susceptibilities. European Journal of Clinical Microbiology \& Infectious Diseases, v. 31, p. 1647-1652, 2012.

MAZIARZ, M.D.E.K.; PERFECT, M.D.J.R. Cryptococcosis. Infectious Disease Clinics of North America, v. 30, p. 179-206, 2016.

MENEZES, T.; SCAIN, G.; QUADROS, R.M.; MILETTI, L.C.; SOUZA, A.L.; MIGUEL, R.L., et al. Cryptococcus spp. em excretas de pombos (Columba livia) de áreas públicas de lages, Santa Catarina. Science and Animal Health, v. 2, p. 102-114, 2014.

MEZZARI, A.; WLIEBBELLING, A.M.P.; WENCZENOVICZ, C.; SOUZA, C.D.A.; FREITAS, G.S. O.; BARBOZA, L.D.; et al. Presença do Cryptococcus spp. nas excretas de pombos nos arredores de Hospitais de Porto Alegre. Revista Panamericana de Infectología, v. 16, p. 153-160, 2014.

MIRANDA, C.; LADENDORFF, N.; KNÖB, T. Percepção da população sobre a participação dos pombos (Columba livia domestica) na transmissão de zoonoses. Atas de Saúde Ambiental, v. 2, p. 23-28, 2014.
MOREIRA, L.A.; BATISTA, S.C.; GRITTI, A.; SILVA, J.B.M.; VIDO, M.H.C. Meningoencefalite causada por Cryptococcus neoformans em pacientes portadores de HIV/AIDS. Revista Educação em Foco, v. 9, p. 72-81, 2017.

MUKAREMERA, L.; LEEB, K.K.; WAGENERB， J.; WIESNERA, D.L.; GOWB, N.A.R.; NIELSENA, K. Titan cell production in Cryptococcus neoformans reshapes the cell wall and capsule composition during infection. The Cell Surface, v. 1, p. 15-24, 2018.

NUNES, J.O.; TSUJISAKI, R.A.S.; NUNES, M.O.; LIMA, G.M.E.; PANIAGO, A.M.M.; PONTES, E.R.J.C.; et al. Cryptococcal meningitis epidemiology: 17 years of experience in a State of the Brazilian Pantanal. Revista da Sociedade Brasileira de Medicina Tropical, v. 51, p. 485492, 2018.

NWEZE, E.I.; KECHIA, F.A.; DIBUA, U.E.; EZE, C.; ONOJA, U.S. Isolation of Cryptococcus neoformans from environmental samples collected in southeastern Nigeria. Revista do Instituto de Medicina Tropical de São Paulo, v. 57, p. 295-298, 2015.

PAES, H.C.; FRAZÃO, S.O.; ROSA, C.P.; ALBUQUERQUE, P.; CASADEVALL, A.; FELIPE, M.S.S.; et al. Opsonin-free, real-time imaging of Cryptococcus neoformans capsule during budding. Virulence, v. 9, p. 1483-1488, 2018.

PANG, W.; SHANG, P.; LI, Q.; XU, J.; BI, L.; ZHONG, J. et al. Prevalence of opportunistic infections and causes of death among hospitalized HIV-infected patients in Sichuan, China. The Tohoku Journal of Experimental Medicine, v. 244, p. 231-242, 2018.

PEDROSO, R.S.; FERREIRA, J.C.; CANDIDO, R. C. The isolation and characterization of virulence factors of Cryptococcus spp. from saprophytic sources in the city of Ribeirão Preto, São Paulo, Brazil. Microbiological Research, v. 164, p. 221-227, 2009.

RAJASINGHAM, R.; SMITH, R.M.; PARK, B.J.; JARVIS, J.N.; GOVENDER, N.P.; CHILLER, T.M. et al. Global burden of disease of HIV-associated cryptococcal meningitis: an updated analysis. The Lancet Infectious Diseases, v. 17, p. 873-881, 2017.

REOLON, A.; PEREZ, L.R.R.; EMEZZARI, A. Prevalência de Cryptococcus neoformans nos pombos urbanos da cidade de Porto Alegre, Rio Grande do Sul. Jornal Brasileiro de Patologia e Medicina Laboratorial, v. 40, p. 293-298, 2004.

RIBEIRO, M.F.P.; SILVA, A.M.; FERNANDES, W.S.; MELLO, M.M. Isolamento de Cryptococcus neoformans em fezes de pombos (Columba livia) em praças públicas de São José dos Campos-SP. Journal of the Health Sciences Institute, v. 35, p. 23-27, 2017.

ROBERT, V.; CARDINALI, G.; CASADEVALL, A. Distribution and impact of yeast thermal tolerance permissive for mammalian infection. BMC Biology, v. 13, p. 1-14, 2015.

ROSA, G.; MERLINI, L.S.; BESSI, W.H.; GONÇALVES, 
A.P.P.; SILVA, L.Z.; PERUSSI, P.R.; et al. Survey of Cryptococcus neoformans in pigeon (Columba livia) excreta in Public Square in Umuarama, Paraná, Brazil. African Journal of Microbiology Research, v. 10, p. 1844-1848, 2016.

TAKAHARA, D.T.; LAZÉRA, M.S.; WANKE, B.; TRILLES, L.; DUTRA, V.; PAULA, D.A.J.; et al. First reporton Cryptococcus neoformans in pigeon excreta from public and residential locations in the metropolitan area of Cuiabá, state of Mato Grosso, Brazil. Revista do Instituto de Medicina Tropical de São Paulo, v. 55, p. 371-376, 2013.

TORTORA, G. J.; FUNKE, B. R.; CASE, C.L. Microbiologia. 12a . ed. Porto Alegre: Artmed; 2017. p. 626627.

TRILLES, L.; MEYER, W.; WANKE, B.; GUARRO, J.; LAZÉRA, M. Correlation of antifungal susceptibility and molecular type within the Cryptococcus neoformans/C. gattii species complex. Medical Mycology, v. 50, p. 328332, 2012.

ZARAGOZA, O.; GARCÍA-RODAS, R.; NOSANCHUK, J. D.; CUENCA-ESTRELLA, M.; RODRÍGUEZ-TUDELA, J. L.; CASADEVAL, A. Fungal Cell Gigantism during Mammalian Infection. PLoS Pathogens, v. 16, n. 6, e1000945, 2010. 